\title{
Nadir bir disfaji nedeni: Özofagus tüberkülozu
}

\author{
A rare cause of dysphagia: Esophageal tuberculosis
}

Ahmet KARAMAN ${ }^{1}$, Abdülsamet ERDEN ${ }^{2}$, Hatice KARAMAN ${ }^{3}$

Kayseri Eğitim ve Araştırma Hastanesi, ${ }^{1}$ Gastroenteroloji Kliniği, ${ }^{2}$ Iç Hastalıklanı Kliniği, ${ }^{3}$ Patoloji Departmanı, Kayseri

Tüberküloz ülkemizin ve gelișmekte olan ülkelerin yeniden gündemine gelen bir halk sağllğı problemidir. Immunsupresif ajanların yaygın kullanımı, endemik bölgelerden olan göçler, artan HIV enfeksiyonu gibi sebeplerle gelişmis ülkelerde de tüberküloz sıklığında artış gözlenmektedir. Tüberküloz multisistemik tutulum gösteren histopatolojik olarak kazeifiye granülomlarla karakterize bir enfeksiyon hastalığıdır. Gastrointestinal tüberküloz; Almanya'dan bildirilen tüberküloz olgularının \% 1.2'sini oluşturur ve altıncı en yaygın ekstrapulmoner tüberküloz yeridir. Akla getirilmezse kolayca atlanabilir, tanı gecikebilir ve sonuçta morbidite ve mortalite artabilir. Bu bildiride yutma güçlügü şikayeti ile gelen bir vaka sunulacaktır.

Anahtar kelimeler: Özofagus, tüberküloz

\section{GİRISS}

Tüberküloz ülkemizin ve gelişmekte olan ülkelerin yeniden gündemine gelen bir halk sağlığı problemidir. Immunsupresif ajanların yaygın kullanımı, endemik bölgelerden olan göçler, artan HIV enfeksiyonu gibi sebeplerle gelişmiş ülkelerde de tüberküloz sıklığında artış gözlenmektedir. Tüberküloz multisistemik tutulum gösteren histopatolojik olarak kazeifiye granülomlarla karakterize bir enfeksiyon hastalığıdır. Gastrointestinal tüberküloz; Almanya'dan bildirilen tüberküloz olgularının \% 1.2'sini oluşturur ve altıncı en yaygın ekstrapulmoner tüberküloz yeridir (1). Akla getirilmezse kolayca atlanabilir, tanı gecikebilir ve sonuçta morbidite ve mortalite artabilir. Bu bildiride yutma güçlüğü şikayeti ile gelen bir vaka sunulacaktır.

\section{OLGU}

53 yaşında bir erkek hasta bir aydır süren yutma güçlüğü, halsizlik, gece terlemesi, ateş ve 1 ayda 10 kilo zayıflama şikayetleriyle gastroenteroloji servisine yatırıldı. Nefes darlı̆̆ı, öksürük ve balgamı yoktu. Özgeçmiş ve soy geçmişinde özellik yoktu. Fizik muayenesi normaldi. Kan tetkiklerinde beyaz küre: $4920 \mathrm{~K} / \mathrm{uL}, \mathrm{Hb}: 13.9$ g/dl, Plt: $232000 \mathrm{~K} / \mathrm{ul}$, albumin $3.4 \mathrm{~g} / \mathrm{dL}$, AST $56 \mathrm{U} / \mathrm{l}$, sedimentasyon $35 \mathrm{~mm} / \mathrm{saat}$ ve CRP 97 mg/L idi. Posterior-anterior akciğer grafisinde özellik saptanmadı. Takiplerinde $38.5^{\circ} \mathrm{C}$ 'yi bulan ateşi olan hastaya ampirik olarak seftriakson $2 x 1$ gr intravenöz başlandı. Üst endoskopide özofagus orta alt kısmında 15-20 mm çapında kenarı düzensiz mukozal bir defekt izlendi ve biyopsi alındı (Resim
Tuberculosis is an important public health problem in our country and in the world. Because of the use of immunosuppressive agents, increasing human immunodeficiency virus infection, and immigration, tuberculosis is seen in developed countries as well. Tuberculosis is a multisystemic infectious disease characterized by granulomatous reaction. Gastrointestinal tuberculosis is responsible for $1.2 \%$ of extrapulmonary tuberculosis in Germany. Mortality and morbidity may increase if diagnosis of the disease cannot be done or is delayed. Here, we report a case complaining of dysphagia who was determined to have esophageal tuberculosis.

Key words: Esophagus, tuberculosis

1-2). Seftriakson altında ateşleri devam etmesi üzerine imipenem'e geçildi. Biyopsi sonucu granülamatoz iltihabi olay olarak rapor edildi ve Ziehl-Neelsen (EZN) ile boyamada asidorezistan basil (ARB) negatif olarak bulundu. Tüberkülin deri testi negatif geldi. Üst endoskopisi tekrarlandı tekrar biyopsi alınd. Biyopsi sonucu kronik aktif granülomatöz özofajit olarak rapor edildi. Toraks tomografisinde mediastende perikaval, sol hiler bölgede ve subkarinal bölgede lenfadenopati (LAP) izlendi. Ateşi devam etmesi üzerine amfoterisin B’ye geçildi ancak buna alerji gelişmesi üzerine vorikonozol'e geçildi. Mediastinel LAP'larından mediastinoskopik biyopsi alındı. Ateşleri devam etmesi üzerine antibiyotikleri stoplandı. Mediastinel biyopsi sonucu nekrotizan granülomatöz iltihabi olay olarak geldi (Resim 2). Parafin blok ile hazırlanan dokudan çalışılan PCR'da tüberküloz basili üredi. Hastaya dörtlü antitüberküloz tedavisi (izoniazid $300 \mathrm{mg} /$ gün, rifampisin 600 mg/gün, etambutol 1500 mg/gün, pirazinamid 2gr/gün) başlandi.

\section{TARTISMA}

Gastrointestinal tüberkülozlu vakaların çoğundan mycobacterium tuberculosis sorumlu olmasına rağmen özellikle mycobacterium bovis ile enfekte süt ürünleri iyi pastörize edilmezse enfeksiyon kaynağı olabilir. Ajanın doğal bulaş yolu oral alındiktan sonra direkt mukozal penetrasyondur. Bu, aktif tüberkülozda enfekte balgamın yutulması, kontamine sütün içilmesi ile olabilir. Bunun dışında aktif pulmoner tü- 

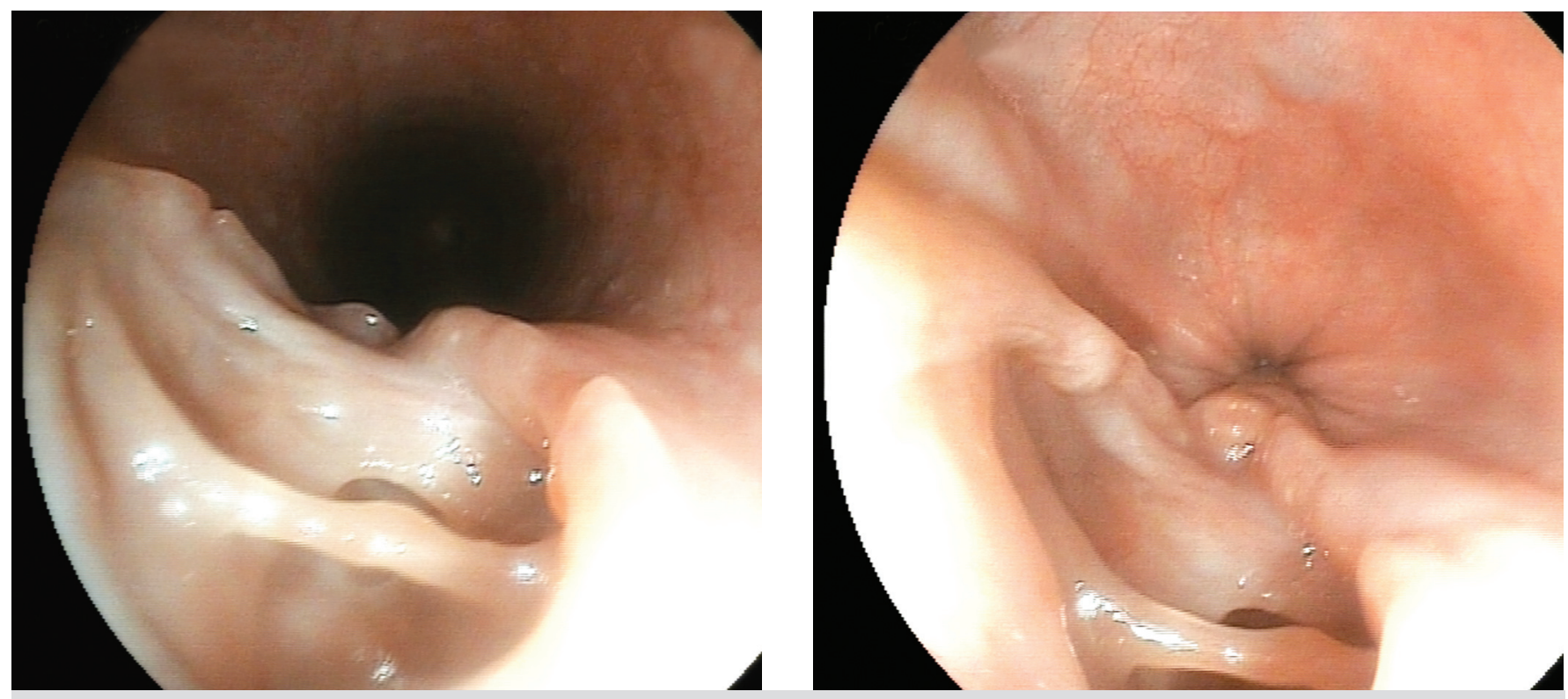

Resim 1-2. Özofagus mukozasındaki mukozal defekt (litik-nekrotik lezyon) ve köprüleşmenin endoskopik görünümü.

berkülozun hematojen yayılımı, miliyer tüberküloz, tüberkülozun primer fazında bakteriyemi veya komşu organlardan direkt yayllım ile gelişebilir. Intesinal tüberküloz her yaşta görülebilir. ABD ve Avrupa ülkelerinde en sık 50-75 yaşları arasında, gelişmekte olan ülkelerde ise 20-40 yaşları arasında görülür $(2,3)$. Kadın ve erkeklerde eşit sıklıkta bulunur. Çoğu olguda semptomlar aylar öncesinde başlamıştır. Ancak vakaların \%20'sinde bir aydan daha kısa süreli klinik anamnez vardır. Ana semptom disfajidir (4). Diğer semptomlar odinofaji, ateş, kilo kaybı ve retrosternal ağnıdır. Intesinal tüberküloz için spesifik laboratuvar bulguları yoktur. En sık görülen bozukluklar anemi, sedimentasyon yüksekliği, lenfositoz, trombositoz ve hipoalbüminemidir $(5,6,7)$. Gastrointestinal tüberküloz vakaların $\% 75$ inde tutulum yeri ileoçekal bölge veya jejenumdur. Daha sonra sıklık sırasına göre çıan kolon, jejunum, apendiks, duodenum, mide, özofagus, sigmoid kolon ve rektum tutulur. Tüberkülozun çok sik görüldügü yerlerde bile primer özofagus tutulumu çok nadirdir (8). 20.yüzyılın başlarından yapılan bir çalışmada da 16489 tüberkülozlu vakaların otopsilerinde sadece $\% 0.15$ olarak özofagus tutulumu bulunmuştur (9). Tüberküloz özofagus tutulumu genellikle karina düzeyinde, özofagusun orta kısmını etkiler (10). Özofagus tutulumu ya subkarinal lenf gangliyonlarından doğrudan yayllım ile ya da basillerin yutulması ile olur ve genelde orta 1/3'ünde ülser şeklindedir. Iyileşirken traksiyon divertikülleri yapabilir. Intestinal tüberkülozda barsak duvarı kalınlaşır. Çevresinde inflamatuvar bir kitle görülür. Endoskopide mukoza hiperemik, kaldırım taşı manzarasında, bar- sak uzun ekseninde dik yüzeyel ülserasyonlar görülebilir. Bizim sunduğumuz olguda lezyonun tutulum yeri benzer olmakla birlikte tutulum şekli ülserden daha çok mukozal bir defekt şeklinde idi. Intestinal tüberküloz tanısında endoskopi ve bu sırada alınan biyopsi tanıda çok değerlidir. Biyopsiden iyi sonuç almak için parçanın ülser olan olgularda ülser tabanı ve kenarından, ülser olmayan olgularda ise derin olarak alınması önerilmektedir. Alınan doku Ziehl-Neelsen (EZN) ile boyanarak kazeifiye granülomlar ve asido-rezistan basil (ARB) gösterilebilir (11). Histolojik olarak granülom görülür, kazeifikasyon her zaman görülmeyebilir ancak bölgesel lenf gangliyonlarında kural olarak kazeifikasyon vardır. Parafin blok hazırlanan dokuda PCR yapılması tanıda çok yardımcıdır. Özellikle granülom olmayan olgularda yüksek PCR pozitifliği, yeterli biyopsiye rağmen bir türlü tanı konulamayan olgular için yardımcıdır (12). Vakamızda da biyopsiler sonucu tüberkülozdan şüphelenilmiş ancak ARB negatif bulunmuş, PCR yöntemiyle tanı konulabilmiştir. Ayırıcı tanıda özofagus kanseri, fungal ve viral enfeksiyon, kostik madde alımı, sifiliz ve Crohn hastalı̆ıı vardır (13). Bazı vakalarda özofagus kanserinden ayırıcı tanısı yapılamadığı için gereksiz özofajektomi ile sonuçlanabilir (14). Tanı konulabilmesi için öncelikle tüberkülozun akla gelmesi gerekir. Bu olguyu sunmaktaki amacımız gastrointestinal sistemde tanı konulamayan durumlarda ve lezyonlarda tüberkülozun akla getirilmesi gerekliliğini vurgulamak ve nadir görülen bir durum olan özofagus tüberkülozunu literatüre kazandırmaktır. 


\section{KAYNAKLAR}

1. Bericht zur Epidemiologie der Tuberkulose in Deutschland für 2007 Robert-Koch-Institut. www.rki.de.

2. Horsburgh CR Jr and Nelson AM. Mycobacterial Disease of the Gastrointestinal Tract. In: Infections of the Gastrointestinal Tract. (Eds.Blaser MJ, Smith PD, Ravdin JI, Greenberg HB, Gurrant RL) Raven Press, New York, 1995;937-55.

3. Bhansali SK. Abdominal tuberculosis. Am J Gastroenterol 1977;67:32437.

4. Mokoena T, Shama DM, Ngakane H, Bryer JV. Esophageal tuberculosis: a review of eleven cases. Postgrad Med J 1992;68:110-5.

5. Mungan Z. Intestinal tüberküloz. Medikal \& Teknik. 1995;105:9-11.

6. Sarıtaş Ü, Sarıçam T, Müftüoğlu V, ve ark. Abdominal tüberkülozis. Türkiye Klinikleri Gastroenterohepatoloji Dergisi 1990;2:89-92.

7. AI Karawi MA, Mohamed AE, Yasawy MI, et al. Protean manifestation of gastrointestinal tuberculosis: report on 130 patients. J Clin Gastroenterol 1995;20:225-32
8. Rosario MT, Raso CL, Comer GM. Esophageal tuberculosis. Dig Dis Sci 1989;34:1281-4.

9. Lockard LB. Oesophageal tuberculosis: a critical review. Laryngoscope 1913;23:561-84.

10. Marshall JB. Tuberculosis of the gastrointestinal tract and peritoneum. Am J Gastroenterol 1993;88:989-99.

11. Kim KM, Lee A, Choi KY, Lee KY, et al. Intestinal tuberculosis: Clinicopathologic analysis and diagnosis by endoscopic biopsy. Am J Gastroenterol 1998;93:606-9.

12. Anand BS, Schneider FE, El-Zaatari FA, et al. Diagnosis of intestinal tuberculosis by polymerase chain reaction on endoscopic biopsy specimens. Am J Gastroenterol 1994;89:2248-9.

13. Gupta SP, Arora A, Bhrgava DK. An unusual presentation of esophageal tuberculosis. Tuberc Lung Dis 1992;73:174-6.

14. Sinha SN, Tesar P, Seta W, Sengupta SK. Primary esophageal tuberculosis. Br J Clin Pract 1988;42:391-4. 